\title{
SOCIAL ENTREPRENEURSHIP THAT TRULY BENEFITS THE POOR AN INTEGRATIVE JUSTICE APPROACH
}

NICHOLAS J.C. SANTOS S.J.

Marquette University

Milwaukee, Wisconsin, U.S.A.

nicholas.santos@marquette.edu

\begin{abstract}
The phenomenal growth of social entrepreneurship over the last decade has ably demonstrated how technology, innovation, and an entrepreneurial spirit can afford better solutions to the vexing social and environmental problems of our time than can traditional aid and charitybased efforts. In most cases, but not always, the poor and disadvantaged have benefited from the growth of social entrepreneurship. In order to ensure that social entrepreneurship does indeed benefit the poor, it is imperative that there be normative guidelines for fair and just engagement with impoverished populations. A model that has been presented in the marketing and public policy literature is the integrative justice model (IJM) for impoverished populations. While the IJM was developed primarily in the context of multinational corporations (MNCs) operating in emerging markets, its applicability extends beyond MNCs. This article attempts to apply the IJM principles in the context of social entrepreneurship in order to provide social entrepreneurial organizations (SEOs) with a normative framework aimed at ensuring that the poor truly benefit from their activities. Based on this framework, the article suggests certain areas to which SEOs ought to be particularly attentive in their practice. The article also makes some suggestions for further research.
\end{abstract}




\section{INTRODUCTION}

In July 2010, the Oxford Poverty and Human Development Initiative (OPHI) of Oxford University and the Human Development Report Office of the United Nations Development Programme (UNDP) launched a new poverty measure called the Multidimensional Poverty Index (MPI) (United Nations Development Programme, 2011). The MPI uses the same three dimensions as the Human Development Index: Health, Education, and Living Standards. However, it shows the number of people who are multidimensionally poor, that is, those who suffer deprivations in $33 \%$ or more of the weighted indicators. The ten indicators considered are: Nutrition, Child Mortality, Years of Schooling, School Attendance, Cooking Fuel, Sanitation, Drinking Water, Electricity, Flooring, and Assets (Alkire, Roche, \& Seth, 2013; Alkire \& Santos, 2010). About 1.7 billion people in the 109 countries covered by the MPI live in conditions reflecting acute deprivation in health, education, and standard of living. Even in an affluent country like the U.S., about one in six people lives in poverty (Crary, 2011; U.S. Census Bureau, 2011).

A traditional approach to alleviating poverty in the developing world has been through development aid. This approach, however, though still supported strongly by some development economists such as Jeffrey Sachs (2005), has not met with much success in the fight against poverty. Rangan and McCaffrey (2004) argue that although trillions of dollars were expended by way of investment and aid to developing countries in a twenty-five year timeframe, hardly a dent was made in global poverty. Prahalad (2005: 3) echoes this position and points out that "for more than 50 years, the World Bank, donor nations, various aid agencies, national governments, and lately, civil society organizations have all fought the good fight, but have not eradicated poverty." Within this scenario, there have been two emerging trends in low-income markets, characterized as the base or bottom of the pyramid (BoP) market. One is a growing interest of multinational corporations (MNCs) in this segment; the other is social entrepreneurship.

Evidence for the first trend is contained in "The Next Billions: Unleashing Business Potential in Untapped Markets" (World Economic Forum \& Boston Consulting Group, 2009), a report released at the annual meeting of the World Economic Forum in 2009. Examples of MNCs that have ventured into the BoP market in recent years include Unilever (Prahalad, 2005; Rangan, Sehgal, \& Rajan, 2007), Cemex (Prahalad, 2005; Segel, Meghji, \& García-Cuéllar, 2007), Kodak (Dikkers \& Motta, 2007), Nestle (Simonian, 2006), and Proctor and Gamble (Silverman, 2006). Historically, the limited purchasing power of the low-income segment acted 
as a deterrent to the economic involvement of MNCs with this group (Prahalad, 2005). Thought of in classic "definition of a market" terms, the poor may have the desire for goods and services but they simply lacked sufficient ability to constitute a viable market segment. This financial hurdle was overcome by multiple analyses demonstrating that there was a profit potential in the BoP market (Hammond, Kramer, Katz, Tran, \& Walker, 2007; Prahalad, 2005). For firms experiencing saturation in servicing many high and middle income markets, along with an excess in production capacity, seeking growth opportunities in the BoP market is a logical strategy from a business perspective (Christensen, Raynor, \& Anthony, 2003; Hart, 2007; Johnson \& Nhon, 2005; Prahalad, 2005; Schultz, Rahtz, \& Speece, 2004).

Evidence of the second trend was the 2006 Nobel Peace Prize awarded to Muhammad Yunus and the Grameen Bank (Nobel Foundation, 2006). In their press release, the Nobel Prize Committee acknowledged the role that an innovative solution such as micro-credit plays in poverty elimination. Over the last few decades, there has been an increase in entrepreneurial and innovative solutions to some of the vexing social and/or environmental problems of our time.

In addition to the Grameen Bank that pioneered micro-credit, examples of organizations that have developed innovative solutions to social and/or environmental problems include Husk Power Systems (biomass gasification using rice husk, www.huskpowersystems.com), Solar Sister (women-centered direct sales network to bring solar technology to rural Africa, www.solarsister.org), Gram Vikas (integrated model of rural community development, www.gramvikas.org), and Fundacion Paraguaya (financially self-sufficient educational institutions, www.fundacionparaguaya.org.py), among many others.

Since its inception in 2003, and on through 2012, the Global Social Benefit Incubator (GSBI) at Santa Clara University in California has helped over 150 socially-minded entrepreneurs "to build sustainable, scalable organizations and solve problems for people living in poverty around the world" (http://www.scu.edu/socialbenefit/entrepreneurship/ gsbi/). Ashoka, the organization that Bill Drayton founded in 1980 to support social entrepreneurs, has about 3,000 Fellows in over 70 countries (www.ashoka.org). Created by Jeff Skoll in 1999, the Skoll Foundation has driven large-scale solutions to the world's pressing problems. Over a period of 13 years, the foundation awarded more than \$358 million, supporting around 97 social entrepreneurs and 80 organizations in five continents around the world (www.skollfoundation.org). 
Academic interest in the field of social entrepreneurship has also grown substantially. An internet search conducted by Huybrechts and Nicholls (2012: 32) in March 2011 using EBSCO and Google Scholar identified about 75 articles and 23 books on the topic of social entrepreneurship. In addition, journals such as the Social Enterprise Journal (Emerald) and the Journal of Social Entrepreneurship (Routledge) were created to focus on the area of social entrepreneurship. There has also been a growing interest in social entrepreneurship as a career choice (Hodgson, 2012).

The first trend, namely that of MNC involvement in the BoP, offers on one hand the hope of a more inclusive capitalism and of empowering market segments that were previously kept at the periphery of economic development. However, on the other hand, given the historical exploitation of these segments by business entities, there is also a growing concern about the danger of greater exploitation of poor and disadvantaged populations. Such exploitative practices have included predatory lending, tainted insurance, unconscionable labor practices, and exorbitant rentto-own transactions (Grow \& Epstein, 2007; Hill, Ramp, \& Silver, 1998; Karpatkin, 1999; Murphy, Laczniak, Bowie, \& Klein, 2005; Young, 2006). In order to enhance fairness when engaging BoP populations, Santos and Laczniak (2009a) have proposed a normative ethical model labeled the integrative justice model (IJM) for business with impoverished populations.

The IJM is constructed using a normative theory building process from the discipline of philosophy and is comprised of ethical elements that ought to be present when fairly and justly marketing to the poor (Bishop, 2000; Santos \& Laczniak, 2012). The key elements of the IJM have been derived from moral philosophy theories, corporate social responsibility frameworks, and religious doctrine.

I begin the remainder of this article with an elaboration of the IJM. I then highlight the foundational principles of Catholic social teaching, the religious doctrine from which the IJM elements are derived. The growth of the field of social entrepreneurship has been accompanied by a relatively high degree of uncertainty as to what constitutes its domain. I therefore draw on some current understandings of social entrepreneurship and suggest a working definition of a social entrepreneurial organization (SEO). The purpose of such a definition is to provide a basis for modifying the IJM so as to suggest principles that are more aptly suited to the context of social entrepreneurship.

As the focus of SEOs is on social impact, such a goal is considered an a priori good. As a result, it might appear that SEOs are exempt from the need for an ethical framework. But an end, however worthy and noble, can be pursued through means that might not be so. An ethical 
framework therefore provides a basis for SEOs to ensure that the means they use are also ethical. To that end, I put forth some implications of the modified IJM for SEOs. I conclude by identifying limitations and making suggestions for further research.

\section{THE INTEGRATIVE JUSTICE MODEL (IJM) FOR IMPOVERISHED MARKET SEGMENTS}

As mentioned earlier, the entry of MNCs in the BoP presents the opportunity for greater involvement of populations that were previously kept at the periphery of economic development. However, owing to the constraints and disadvantages that people in these markets face, there is an increased possibility of exploitation of these populations. With the aim of developing an equitable and fair approach to marketing, especially when directed toward impoverished populations, Santos and Laczniak (2009a) propose a normative ethical framework labeled the "Integrative Justice Model" (IJM) for marketing to the BoP.

The IJM does not integrate different types of justice such as legal justice, procedural justice, etc. Instead, in the realm of distributive justice, it integrates the notions of fairness and equity as presented in various strands of thought in moral philosophy, management theory, and religious doctrine (Santos \& Laczniak, 2009b, 2009a). These perspectives are:

1. Catholic social teaching;

2. Habermas' discourse theory;

3. Kant's categorical imperative;

4. Rawls' difference principle;

5. Ross' theory of duties;

6. Sen's capability approach;

7. Virtue ethics;

8. Classical utilitarianism;

9. Service-dominant logic of marketing;

10. Socially responsible investing;

11. Stakeholder theory;

12. Global sustainability; and

13. the Triple bottom line.

See Appendix A for a brief synopsis of these theories.

These perspectives, when examined together, reveal five key elements of "just" and "fair" markets especially when involving impoverished 
populations (see Appendix B for the theoretical support of these elements and Appendix $\mathrm{C}$ for the IJM model). These five elements are:

1. Authentic engagement with consumers, particularly impoverished ones, with non-exploitative intent;

2. Co-creation of value with customers, especially those who are impoverished or disadvantaged;

3. Investment in future consumption without endangering the environment;

4. Interest representation of all stakeholders, particularly impoverished customers; and

5. Focus on long-term profit management rather than on short-term profit maximization.

While the above elements are not intended to be an exhaustive list of "just" and "fair" marketing with impoverished populations, they can be seen as distinct and symbiotic dimensions of what constitutes a "just" marketplace. These dimensions are not fragmented and isolated ones, but are rather to be considered in their entirety as interdependent and related characteristics. In the following section, I summarize Catholic social teaching, one of the frameworks on which the IJM is based.

\section{CATHOLIC SOCIAL TEACHING}

Catholic social teaching (CST) refers to the corpus of Church documents that relate to the Church's response and commitment to the social demands of the gospel in the context of the world (Santos \& Laczniak, 2009b). A generally accepted starting point for the Catholic social tradition is Pope Leo XIII's encyclical in 1891 entitled Rerum Novarum which was a response to many of the social abuses that were taking place in the Industrial Revolution. The four foundational principles of the Church's social doctrine are: (a) the dignity of the human person, (b) the common good, (c) subsidiarity, and (d) solidarity (Pontifical Council for Justice and Peace, 2004).

The principle of human dignity affirms that human life is sacred and that human beings, by virtue of being created in God's image, have an inviolable dignity. Such dignity is not something that human beings acquire by their efforts but rather is an intrinsic part of what it means to be human. The principle of human dignity implies that all persons, 
regardless of race, color, and creed, ought to be treated with full respect. Treating people as objects would be a violation of the principle of human dignity.

The second principle, namely that of the common good, is broadly understood as the overall social conditions that enable individuals or groups to attain their fulfillment more easily (Pontifical Council for Justice and Peace, 2004). Unlike the utilitarian approach, which focuses on the greatest good for the greatest number, the principle of the common good is geared toward the benefit of all. The principle implies that the goods of the earth have been given for all to use and therefore all people have a right to benefit from their use. This implication does not mean that the Church opposes private ownership-in fact, the Catholic Church has been a strong proponent of the right to private property, but it holds that all people should have equal access to the ownership of goods and property (John Paul II, 1991; Pontifical Council for Justice and Peace, 2004).

The third principle of subsidiarity refers to helping or supporting lower or subordinate levels to achieve their fulfillment while respecting their freedom. The word "subsidiarity" comes from the Latin subsidium, which means help. Thus, subsidiarity does not merely mean delegating power to lower levels but also creating structures that better enable the exercise of that power. A major implication of subsidiarity is that of participation in the common good.

The final principle, solidarity, affirms the intrinsic social nature of the human person. As Pope John Paul II (1988: 420) reminds us, solidarity is not just a "feeling of vague compassion or shallow distress at the misfortunes of so many people, both near and far. On the contrary, it is a firm and persevering determination to commit oneself to the common good." The principle of solidarity "expresses in summary fashion the need to recognize in the composite ties that unite men and social groups among themselves, the space given to human freedom for common growth in which all share and in which they participate" (Pontifical Council for Justice and Peace, 2004: 86).

The four foundational principles of CST mentioned above provide a helpful guiding structure to ensure that entrepreneurial initiatives do indeed benefit the poor. With regard to social entrepreneurship, the Catholic Church's support for this growing field is perhaps evident, though not explicitly mentioned, in Pope Benedict's third encyclical Caritas in Veritate (Benedict XVI, 2009). Simha and Carey (2012) utilize a hermeneutic approach and contend that the central message of Pope Benedict's encyclical supports social entrepreneurship endeavors. 


\section{A WORKING DEFINITION OF A SOCIAL ENTREPRENEURIAL ORGANIZATION (SEO)}

The growth of social entrepreneurship over the last few decades has been accompanied by a relatively high degree of ambiguity about its defining characteristics and the elements that distinguish it from for-profit or non-profit enterprises. The Skoll Foundation defines social entrepreneurs as "society's change agents, creators of innovations that disrupt the status quo and transform our world for the better." However, many for-profit organizations would fit this definition too. As Martin and Osberg (2007) point out, confusion arises because "both the entrepreneur and the social entrepreneur are strongly motivated by the opportunity they identify, pursuing that vision relentlessly, and deriving considerable psychic reward from the process of realizing their ideas." What distinguishes social entrepreneurs from other entrepreneurs, however, is that social benefit and "social mission achievement" are the central concerns for social entrepreneurs (Kickul \& Lyons, 2012). Martin and Osberg (2007: 35) define social entrepreneurship as having the following three components:

1. Identifying a stable but inherently unjust equilibrium that causes the exclusion, marginalization, or suffering of a segment of humanity that lacks the financial means or political clout to achieve any transformative benefit on its own;

2. Identifying an opportunity in this unjust equilibrium, developing a social value proposition, and bringing to bear inspiration, creativity, direct action, courage, and fortitude, thereby challenging the stable state's hegemony; and

3. Forging a new, stable equilibrium that releases trapped potential or alleviates the suffering of the targeted group, and through imitation and the creation of a stable ecosystem around the new equilibrium, ensuring a better future for the targeted group and even society at large.

After analyzing twenty definitions during the period 1997-2007, Zahra, Gedajlovic, Neubaum, and Shulman (2009: 522) suggest that "social entrepreneurship encompasses the activities and processes undertaken to discover, define, and exploit opportunities in order to enhance social wealth by creating new ventures or managing existing organizations in an innovative manner." Zahra et al. (2009) identify three types of social entrepreneurs: Social Bricoleur, Social Constructionist, and Social Engineer. Social Bricoleurs focus on local social needs, Social 
Constructionists introduce reforms and innovations to the broader social system, and Social Engineers introduce revolutionary change to address systemic problems within existing social structures.

Huybrechts and Nicholls (2012) point out that there are three features of social entrepreneurship which are common to most definitions. The first is the primacy of social and environmental outcomes over profit maximization. The second feature is an innovative mindset that is manifested in new organizational models and processes, and in new ways of framing societal challenges to arrive at new solutions to these challenges. The third feature is market orientation.

According to Huybrechts and Nicholls (2012), while those three features have perhaps been historically present in organizations, the recent acceleration in social entrepreneurial discourse arises from four main drivers. The first is an explosion of global challenges in areas such as "climate change and environmental degradation; inequality and poverty; lack of access to basic healthcare, clean water and energy; mass migration; international terrorism" (Huybrechts \& Nicholls, 2012: 40). The second driver is the rise of social media which has increased global connectedness among people and increased the ability to identify and respond to social and environmental needs. The third driver is a redefinition of the role of the state, and the fourth is a growing challenge to sustain social organizations.

Analyzing a variety of definitions in the literature, Dacin, Dacin, and Tracey (2011) suggest four key factors that definitions of social entrepreneurship focus on. These are: (1) the characteristics of the individual social entrepreneurs; (2) their sphere of operation; (3) the processes and resources used by the social entrepreneurs; and (4) the mission of the social entrepreneurs. According to Dacin et al., the factor that holds the most promise for the field is the mission of the social entrepreneur: to create social value by providing solutions to social problems.

Based on the discussion above, and utilizing a term used by Mair, Battilana, and Cardenas (2012), I arrive at the following working definition:

A social entrepreneurial organization (SEO) is one that aims at co-creating social and/or ecological value by providing innovative and lasting solutions to social and/or environmental problems through a process of empowerment and in a financially sustainable manner.

SEOs as understood by this definition could be for-profit, not-forprofit, cooperative, hybrid, etc. 


\section{A MODIFIED IJM FOR SEOS}

While the primary focus of an MNC is the profit motive, that of a SEO is to provide innovative and lasting solutions to social and/or environmental problems. As such, there could be operational and organizational characteristics that differentiate a SEO from an MNC. In the following paragraphs, I discuss some of the differences so as to propose a modified IJM that is better suited to the context of SEOs.

In the original IJM, the first key element was authentic engagement with non-exploitative intent. In the case of SEOs, however, the issue of exploitative intent almost becomes superfluous. Such redundancy arises from the benevolent nature of most SEOs, a characteristic that is also true of charitable organizations. In contrast to MNCs that are largely focused on individual gain and profit, SEOs are oriented toward others and are focused on creating social value. This shift in focus reduces the chances of exploitation although it may not completely eliminate the possibility of exploitative occurrences.

A key differentiator between MNCs and SEOs is that, in the case of the latter, social impact is the primary focus. Although MNCs may create social wealth, such creation is often a by-product of the process of economic value creation unlike in the case of SEOs where social value creation is the primary objective (Seelos \& Mair, 2005). This perspective, however, then creates the problem of distinguishing non-profit SEOs from other non-profit enterprises because all of these organizations are focused on social impact and social value creation. A key differentiator between non-profit SEOs and other non-profit organizations is that the former seeks to empower its beneficiaries, particularly those who are most disadvantaged or marginalized. According to Müller (2012), Grameen Bank was able to empower women through microloans and to build on the resource pool of ideas, motivation, and skills that these women already possessed.

Müller (2012) distinguishes between the business models of social entrepreneurs, commercial entrepreneurs, and traditional non-profit organizations along three dimensions: value proposition, value architecture, and revenue model. According to Müller (2012: 116), "the social entrepreneur's value proposition is typically linked to mitigating social or environmental problems"; "they want to eliminate the root cause of the problem." This latter point perhaps distinguishes SEOs from traditional non-profits that also work in the same problem areas but usually focus more on providing instant relief (a BandAid) rather than on solving the root cause of the problem. So, for instance, a soup kitchen does a yeo- 
man service in providing food to people who do not have food for their sustenance. However, the soup kitchen does not enquire into the reasons why people who benefit from their services do not have food to eat, and if something can be done about their situation. These are inquiries SEOs would typically make and act upon.

Co-creating value that is aimed at solving root causes of the problems of poverty implies collaborating with those affected by poverty in order to determine those root causes, as well as to devise solutions and then deliver them. An organization that exemplifies this approach is Gram Vikas, a social enterprise and rural development organization headquartered in Orissa, India (Pless \& Appel, 2012). Gram Vikas' success is driven by the concept of $100 \%$ inclusion that involves "participatory decision making processes, shared responsibility taking and equal opportunities" (Pless \& Appel, 2012: 389). The inclusion of the various stakeholders, and particularly disadvantaged groups, in the entire value creation process results in each of these groups assuming ownership of the solution and its delivery. Such an approach has a greater possibility of being sustained over a longer period of time, as Gram Vikas's longevity illustrates-it has been 34 years since its formal registration in 1979 (Pless \& Appel, 2012).

In the first editorial essay for the Journal of Management for Global Sustainability (JMGS), the editorial board emphasized that global sustainability "involves the creation and maintenance of a world that works for everyone with no one left out" (Stoner, 2012: 3). The phrase "sustainable ecosystems" used in the IJM proposition conforms to the understanding of global sustainability that the JMGS editorial board puts forth, and not to the narrow interpretation of the words "sustainable" or "sustainability" as referring to a call for "continuing and unending business success." Creating a sustainable ecosystem implies fostering conditions that would enhance human and ecological flourishing not just in the present but also in the future.

Hockerts (2010) hopes that future research in the area of social entrepreneurship will shift the focus from the individual and the organization to sectoral phenomena. The creation of sustainable ecosystems would support such a shift in focus but would also require cross-sectoral collaboration. To elaborate, it is not sufficient for a SEO to focus on a single aspect of poverty because poverty has various dimensions that are often inter-related. Creating a sustainable ecosystem would require individual SEOs to collaborate not just within their sector but also across sectors. Montgomery, Dacin, and Dacin (2012) term such collaboration "collective social entrepreneurship." 
With respect to interest representation, it is important for the enterprise to consider the interests of all its stakeholders and to take these into account, whatever the organizational form might be-whether a MNC, traditional non-profit, or SEO. Interest representation of stakeholders does not imply balancing the competing claims of these stakeholders but rather is aimed at giving due consideration to the interests of all in such a manner that no stakeholder is disadvantaged.

Many development aid efforts did not achieve their intended purpose because the interests of the poor clients were often not represented (Rangan \& McCaffrey, 2004). Interest representation of all stakeholders can better take place if there is participation of stakeholders at different levels. This approach was the one Gram Vikas adopted through its participatory decision-making (Pless \& Appel, 2012).

As SEOs are mostly long-term oriented, the issue of short-term profit maximization does not usually arise. At the same time, it is important for the SEO to be financially viable and sustainable as an institution over time. While financial viability might be attained through the procurement of funds (contributed income) or through commercial activities (earned income), an important consideration needs to be the efficient utilization of resources. Outcomes measurement and social impact assessment are tools that are gaining significance in helping SEOs be more financially effective and efficient.

Based on the discussion in the preceding paragraphs, I suggest replacing the "nonexploitative intent" component of the first IJM element with "empowerment particularly of disadvantaged groups." Likewise, the second IJM element should be modified to include social and/or environmental value creation that is aimed at solving root causes of problems. Furthermore, the third IJM element should be modified from "investing in future consumption, without endangering the environment" to "creation of sustainable ecosystems." The fourth and fifth IJM elements do not need much modification. Interest representation of all stakeholders is true for MNCs and SEOs. In the case of SEOs, the fifth element can focus on financial viability. Table 1 compares the IJM elements for MNCs and SEOs.

\section{IMPLICATIONS OF THE IJM APPROACH FOR SEOS}

An often-heard criticism of normative approaches is that they are often too general to be of practical use to managers (Marcoux, 2000). To respond to that criticism, Santos and Laczniak (2012) propose decision 
principles for each of the IJM characteristics that MNC managers can use as valuable markers in their decision making (see Appendix D). It is beyond the scope of this article to engage in a similar exercise for SEOs. Such an endeavor is something I propose to undertake in the not too distant future. However, based on the IJM, we can generate a checklist of areas that SEO managers ought to consider.

\begin{tabular}{|c|c|c|}
\hline & IJM for MNCs & IJM for SEOS \\
\hline 1 & $\begin{array}{c}\text { Authentic engagement } \\
\text { with consumers, } \\
\text { particularly impoverished } \\
\text { ones, with non-exploitative } \\
\text { intent }\end{array}$ & $\begin{array}{l}\text { Authentic engagement aimed } \\
\text { at empowerment particularly of } \\
\text { disadvantaged groups }\end{array}$ \\
\hline 2 & $\begin{array}{l}\text { Co-creation of value with } \\
\text { customers, especially those } \\
\text { who are impoverished or } \\
\text { disadvantaged }\end{array}$ & $\begin{array}{c}\text { Social and environmental value } \\
\text { co-creation aimed at solving the } \\
\text { root causes of problems associated } \\
\text { with poverty }\end{array}$ \\
\hline 3 & $\begin{array}{c}\text { Investment in future } \\
\text { consumption without } \\
\text { endangering the } \\
\text { environment }\end{array}$ & $\begin{array}{l}\text { Creation of sustainable ecosystems } \\
\text { through a process of innovative } \\
\text { social change }\end{array}$ \\
\hline 4 & $\begin{array}{l}\text { Interest representation } \\
\text { of all stakeholders, } \\
\text { particularly impoverished } \\
\text { customers }\end{array}$ & $\begin{array}{l}\text { Interest representation of all } \\
\text { stakeholders, particularly } \\
\text { impoverished and disadvantaged } \\
\text { segments. }\end{array}$ \\
\hline 5 & $\begin{array}{l}\text { Focus on long-term profit } \\
\text { management rather than } \\
\text { on short-term profit } \\
\text { maximization }\end{array}$ & $\begin{array}{l}\text { Financial viability and } \\
\text { sustainability }\end{array}$ \\
\hline
\end{tabular}

Table 1: Comparison between the IJM elements for MNCs and SEOs

Empowerment is a key differentiator between SEOs and non-profit or other social enterprises. A key test for SEOs is to determine whether their processes are aimed at empowering those whom they engage, particularly disadvantaged segments. If the pioneering social entrepreneurs and managers of SEOs still want to maintain the locus of control, then this desire is a likely indication that the SEO might not be organizationally sustainable.

As the majority of SEOs are involved with impoverished populations, it is tempting to assume a paternalistic stance in arriving at solutions 
to the problems facing this population. However, the key to sustainable SEO ventures will be to assume an attitude of humility and to help impoverished populations come up with their own solutions. Such an approach will ensure that the ownership of SEO initiatives resides with the impoverished segment.

Furthermore, cross-sectoral collaboration or "collective social entrepreneurship" (Montgomery et al., 2012) requires humility and is essential for creating sustainable ecosystems. If social entrepreneurs or managers of SEOs are unwilling to participate in collective social entrepreneurship and are instead totally focused on their individual enterprise, then the likelihood of their initiatives being sustainable over time is reduced. Creating sustainable ecosystems requires social entrepreneurs and SEOs to focus on the bigger picture and the common good rather than on their own individual efforts.

Because many social entrepreneurs emerge from local contexts, it is perhaps easier for them to consider the interests of some of the more obvious stakeholders in their local communities. What might be a challenge is to take into account the interests of other stakeholders outside their immediate locales, such as investors or the government. However, as SEOs scale, this challenge might extend to other members of local communities as well. Therefore, it might be imperative for SEOs to devise ways of being more intentional in representing the interests of all their stakeholders, broadly defined.

A major task for SEOs is to be financially sustainable. As SEOs often project an entrepreneurial mindset that is oriented towards the earned income approach, there are reduced possibilities of procuring funds from philanthropic sources. In addition, as SEOs often work in challenging environments, their earned income models are mostly limited by the financial constraints facing their target group. SEOs have to navigate this space and develop innovative ways of being financially sustainable over the longer run.

Finally, the IJM elements are not isolated and fragmented principles, but are rather inter-related ones. Therefore, it is important to consider all five of these characteristics while evaluating the functioning of the SEO. It is the expectation that SEOs that score high on all five elements will indeed benefit their primary target group, the poor, and do so in ways that will reduce the numbers of those in poverty in future generations. Of course, such validation is the task of future research. 
From the discussion in the preceding paragraphs and based on the IJM for SEOs, I propose the following points that SEO managers and executives ought to pay attention to:

- To what extent are our processes and functioning aimed at empowering the constituencies we engage?

- Is there a system in place for shared-control and succession planning?

- Do we co-create solutions with our target groups?

- To what degree do we collaborate with other SEOs-those within the same sector we operate in and those in other sectors?

- What is the composition of the decision makers? Are the voices of marginalized groups included in decisionmaking?

- How does our business plan ensure financial stability not just for the present but also for the foreseeable future?

- Do our approaches to reducing today's problems also reduce the likelihood of the same or similar problems in the future?

\section{LIMITATIONS AND FUTURE RESEARCH}

A major limitation of this article is that it takes a normative model that has been theoretically developed for another context, namely MNC involvement in BoP markets, and tries to modify that model for the context of social entrepreneurship. An alternative approach would have been to engage in a theory building process specific to the field of social entrepreneurship. The reasoning behind the choice of adapting the existing model rather than creating a new one was that the focus in both situations is to create win-win situations for all participants, particularly disadvantaged ones. As such, the derivation process would have been very similar and would have likely resulted in more or less similar elements.

A major contribution of this article has been to present a normative framework for SEOs with the aim of ensuring that the poor truly benefit from social entrepreneurial activities. While some are critical of the nor- 
mative approach as lacking precise guidelines for implementation, such a framework does provide a much more solid basis for evaluating whether SEOs really do benefit the poor than is provided by a purely descriptive approach. That being said, it was not my intention to propose a normative framework in opposition to existing positive theories. I think both theories should and must complement each other. An excellent positive theory to date is that proposed by Filipe Santos (2012); that we share the same last name is purely coincidental. However, what might not be so coincidental, and in keeping with the nature of the field of social entrepreneurship, is future collaborative research between normative and positive theorists. Future descriptive research can evaluate the degree to which the functioning of SEOs conforms to the IJM characteristics. Future research can also attempt to operationalize the model for the context of SEOs.

\section{CONCLUSION}

According to Dees (2012), there are two cultures that are enmeshed in the development of social entrepreneurship-one is the culture of charity and the other that of problem-solving. Dees (2012) identifies five tensions that these cultures create: (1) spontaneous caritas vs. reasoning; (2) sacrifice vs. investment; (3) giving vs. markets; (4) relieving suffering vs. solving problems; and (5) caring for vs. empowering. Dees (2012) recommends five strategies to help align the two cultures. Two of these strategies are to engage supporters in problem-solving and to improve the affective positioning of problem-solving.

In a similar vein, Smith, Besharov, Wessels, and Chertok (2012) highlight the competing demands that the dual focus of social impact and financial sustainability place on managers of SEOs, and develop a theory of leadership for social entrepreneurship. Drawing on paradox research, they propose three meta-skills to help social entrepreneurs navigate these competing demands: acceptance, differentiation, and integration. "Acceptance involves acknowledging competing demands as an inherent part of organizations and learning to live with them. Differentiation focuses on recognizing the unique contributions of each alternative, whereas integration entails simultaneously addressing both alternatives and seeking synergies between them" (Smith et al., 2012: 466).

Undoubtedly, the dual focus on social and environmental impact and on financial sustainability as well as the two cultures of charity and problem-solving create challenges for SEOs. Those challenges call for the development of organizational paradigms that can enable manag- 
ers in SEOs to be more successful in navigating among them. However, as we do develop such paradigms, an important question that we need to continually place before us is whether the poor, who are mostly the intended beneficiaries, are truly benefitting from these efforts. Such a focus is crucial because recent research is indicating that the poor are not always benefitting from MNC engagement in the BoP nor from all social entrepreneurial activities. For instance, Varman, Skalen, and Belk (2012) are critical of ITC's e-Choupal initiative in India. Likewise, Arora and Romijn (2011) hold that BoP initiatives make the big companies richer while adding a few pennies in the pockets of the poor. Furthermore, as these initiatives do not take into account the unequal power relations at the BoP, they can create power structures that further disadvantage the poor. In the context of social entrepreneurship, microlending, which gained prominence particularly after Muhammad Yunus received the Nobel Prize in 2006, is also coming under criticism. Ethnographic research by Karim (2011) is critical of microlending's claim of poverty reduction and of fostering entrepreneurial activity among the poor. While some might dismiss such research as being one-sided or as painting an overly pessimistic picture, it might instead be desirable to allow that research to motivate us to be more intentional in ensuring that social entrepreneurial efforts do indeed benefit the poor. It is hoped that the IJM for SEOs presented in this article provides an impetus for a more intentional engagement with impoverished populations that does indeed benefit them and the environment and thus helps fashion a more humane and sustainable world. Toward this end, the IJM approach calls upon SEO managers to pay special attention to certain areas such as empowerment, co-creation, interest-representation, and financial sustainability. Future longitudinal research can evaluate whether focusing on these areas does indeed help in ensuring that the poor benefit from the activities of the SEO.

\section{REFERENCES}

Alkire, S., \& Santos, M. E. 2010. Acute multidimensional poverty: A new index for developing countries. United Nations Development Programme.

Alkire, S., Roche, J. M., \& Seth, S. 2013. Multidimensional poverty index, http:// www.ophi.org.uk/wp-content/uploads/8-pager-v3-internet.pdf (accessed May $11,2013)$.

Arora, S., \& Romijn, H. 2011. The empty rhetoric of poverty reduction at the base of the pyramid. Organization, 19(4): 481-505.

Benedict XVI. 2009. Caritas in veritate. San Francisco: Ignatian Press.

Bishop, J. D. 2000. A framework for discussing normative theories of business ethics.

Business Ethics Quarterly, 10(3): 563-592. 
Christensen, C. M., Raynor, M. E., \& Anthony, S. D. 2003. Six keys to building new markets by unleashing disruptive innovation, http://hbswk.hbs. edu/item/3374.html (accessed May 11, 2013).

Crary, D. 2011. Behind the poverty statistics: Real lives, real pain. Huffington Post, September 18.

Dacin, T. M., Dacin, P. A., \& Tracey, P. 2011. Social entrepreneurship: A critique and future directions. Organization Science, 22(5): 1203-1213.

Dees, J. G. 2012. A tale of two cultures: Charity, problem solving, and the future of social entrepreneurship. Journal of Business Ethics, 111: 321-334.

Dikkers, M., \& Motta, P. C. 2007. Photography and the low-income classes in Brazil: A case study of Kodak. In V. K. Rangan, J. A. Quelch, G. Herrero \& B. Barton (Eds.), Business Solutions for the Global Poor: 135-143. San Francisco, CA: Jossey-Bass.

Elkington, J. 1998. Cannibals with forks: The triple bottom line of 21 st century business. Stony Creek, CT: New Society Publishers.

Freeman, R. E. 1984. Strategic management: A stakeholder approach. Boston, MA: Pitman.

Freeman, R. E., Harrison, J. S., \& Wicks, A. C. 2007. Managing for stakeholders: Survival, reputation, and success. New Haven: Yale University Press.

Friedman, M. 1962. Capitalism and freedom. Chicago: University of Chicago Press.

Friedman, M. 1970. The social responsibility of business is to increase its profits. The New York Times Magazine, September 13.

Glassman, J. K. 1999. Letting your conscience be your investment guide. Houston Chronicle, February 8: 4.

Grow, B., \& Epstein, K. 2007. The poverty business: Inside U.S. comapnies' audacious drive to extract more profits from the nation's working poor. BusinessWeek, May 21, 2007: 56-67.

Habermas, J. 1990. Moral consciousness and communicative action. (C. Lenhardt \& S. W. Nicholsen, Trans.). Cambridge, MA: MIT Press.

Hammond, A., Kramer, W. J., Katz, R., Tran, J., \& Walker, C. 2007. The next 4 billion: Market size and business strategy at the base of the pyramid, http://pdf.wri.org/n4b_fulltext_hi.pdf (accessed May 11, 2013).

Hart, S. L. 2007. Capitalism at the crossroads: Aligning business, earth, and humanity. New Jersey: Wharton School Publishing.

Hill, R. P., Ramp, D. L., \& Silver, L. 1998. The rent-to-own industry and pricing disclosure tactics. Journal of Public Policy \& Marketing, 17(Spring): 3-10.

Hockerts, K. 2010. Social entrepreneurship between market and mission. International Review of Entrepreneurship, 8(2): 177-198.

Hodgson, D. C. 2012. Social entrepreneurship soars as a career choice: Finding meaning in work and life, http://www.huffingtonpost.com/davidc-hodgson/social-entrepreneurship-career-choice_b_1562949.html?view=screen (accessed May 11, 2013). 
Huybrechts, B., \& Nicholls, A. 2012. Social entrepreneurship: Definitions, drivers, and challenges. In C. K. Volkmann, K. Ernst \& K. O. Tokarski (Eds.), Social entrepreneurship and social business: An introduction and case studies: $31-48$. Springer Gabler.

John Paul II. 1988. Sollicitudo rei socialis (On social concern). In M. Walsh \& B. Davis (Eds.), Proclaiming justice \& peace: Papal documents from Rerum Novarum through Centesimus Annus: 392-431. Mystic, Connecticut: Twenty-third Publications.

John Paul II. 1991. Centesimus annus (Hundredth anniversary of Rerum novarum). In M. Walsh \& B. Davis (Eds.), Promoting justice \& peace: Papal documents from Rerum Novarum through Centisimus Annus: 432-478. Mystic, Connecticut: Twenty-third Publications.

Johnson, K., \& Nhon, X. 2005. Selling to the poor, http://www.time.com/time/ magazine/article/0,9171,1050276,00.html (accessed May 11, 2013).

Kant, I. 1785. Grounding for the metaphysics of morals (J. W. Ellington, Trans.). (1981 ed.). Indianapolis, IN: Hackett Publishing.

Karim, L. 2011. Microfinance and its discontents. Minneapolis, MN: University of Minnesota Press.

Karpatkin, R. H. 1999. Towards a fair and just marketplace for all consumers: The responsibilities of marketing professionals. Journal of Public Policy \& Marketing, 18(Spring): 118-122.

Kickul, J., \& Lyons, T. S. 2012. Understanding social entrepreneurship: The relentless pursuit of mission in an ever changing world. New York, NY: Routledge.

Laczniak, G. R., \& Santos, N. J. C. 2011. The integrative justice model for marketing to the poor: An extension of S-D logic to distributive justice and macromarketing. Journal of Macromarketing, 31(2): 135-147.

MacIntyre, A. 1984. After virtue: A study in moral theory. Notre Dame, IN: University of Notre Dame Press.

Mair, J., Battilana, J., \& Cardenas, J. 2012. Organizing for society: A typology of social entrepreneuring models. Journal of Business Ethics, 111: 353-373.

Marcoux, A. M. 2000. Business ethics gone wrong. In M. D. Street \& V. L. Street (Eds.), Taking sides: Clashing views in management, 2007 ed.: 13-18. Dubuque, IA: McGraw-Hill.

Martin, R. L., \& Osberg, S. 2007. Social entrepreneurship: The case for definition. Stanford Social Innovation Review, 5(2): 28-39.

McCarthy, T. 2001. Jürgen Habermas. In L. C. Becker \& C. B. Becker (Eds.), Encyclopedia of ethics, 2nd ed., Vol. 2: 643-644. New York: Routledge.

Montgomery, A. W., Dacin, P. A., \& Dacin, M. T. 2012. Collective social entrepreneurship: Collaboratively shaping social good. Journal of Business Ethics, 111: 375-388.

Müller, S. 2012. Business models in social entrepreneurship. In C. K. Volkmann, K. Ernst \& K. O. Tokarski (Eds.), Social entrepreneurship and social business: An introduction and case studies: $105-131$. Springer Gabler. 
Murphy, P. E. 1999. Character and virtue ethics in international marketing: An agenda for managers, researchers, and educators. Journal of Business Ethics, 18(1): 107-124.

Murphy, P. E., Laczniak, G. R., Bowie, N. E., \& Klein, T. A. 2005. Ethical marketing. New Jersey: Prentice-Hall.

Nill, A. L., \& Schultz, C. J., II. 1997. Marketing ethics across cultures: Decision making guidelines and the emergence of dialogic idealism. Journal of Macromarketing, 17(2): 4-19.

Nobel Foundation. 2006. The Nobel Peace Prize, http://www.nobelprize.org/nobel_ prizes/peace/laureates/2006/ (accessed May 11, 2013).

Pless, N. M., \& Appel, J. 2012. In pursuit of dignity and social justice: Changing lives through $100 \%$ inclusion-How Gram Vikas fosters sustainable rural development. Journal of Business Ethics, 111: 389-411.

Pontifical Council for Justice and Peace. 2004. Compendium of the social doctrine of the church. Washington, D.C.: United States Conference of Catholic Bishops.

Prahalad, C. K. 2005. The fortune at the bottom of the pyramid. Upper Saddle River, NJ: Wharton School Pub.

Rangan, V. K., \& McCaffrey, A. 2004. Globalization and the poor. In J. A. Quelch \& R. Deshpande (Eds.), The global market: Developing a strategy to manage across borders: $335-360$. San Francisco, CA: John Wiley \& Sons.

Rangan, V. K., Sehgal, D., \& Rajan, R. 2007. The complex business of serving the poor: Insights from Unilever's project Shakti in India. In V. K. Rangan, J. A. Quelch, G. Herrero \& B. Barton (Eds.), Business solutions for the global poor: Creating social and economic value: $144-154$. San Francisco, CA: Jossey-Bass.

Rawls, J. 1971. A theory of justice. Cambridge, MA: Harvard University Press.

Rawls, J. 1999. A theory of justice (Revised ed.). Cambridge, MA: Harvard University Press.

Ross, W. D. 1930. The right and the good. Oxford: Oxford University Press.

Sachs, J. D. 2005. The end of poverty: Economic possibilities for our time. New York: Penguin Press.

Santos, F. M. 2012. A positive theory of social entrepreneurship. Journal of Business Ethics, 111: 335-351.

Santos, N. J. C., \& Laczniak, G. R. 2009a. Marketing to the poor: An integrative justice model for engaging impoverished market segments. Journal of Public Policy \& Marketing, 28(1): 3-15.

Santos, N. J. C., \& Laczniak, G. R. 2009b. "Just Markets" from the perspective of Catholic social teaching. Journal of Business Ethics, 89: 29-38.

Santos, N. J. C., \& Laczniak, G. R. 2012. Marketing to the base of the pyramid: A corporate responsibility approach with case inspired strategies. Business and Politics, 14(1): Article 4.

Schultz, C. J., II, Rahtz, D. R., \& Speece, M. 2004. Globalization, transformation, and quality of life: Reflections of ICMD-8 and participative marketing and development. Journal of Macromarketing, 24(December): 168-172. 
Seelos, C., \& Mair, J. 2005. Social entrepreneurship: Creating new business models to serve the poor. Business Horizons, 48: 241-246.

Segel, A. I., Meghji, N., \& García-Cuéllar, R. 2007. Patrimonio Hoy: A groundbreaking corporate program to alleviate Mexico's housing crisis. In V. K. Rangan, J. A. Quelch, G. Herrero \& B. Barton (Eds.), Business solutions for the global poor: Creating social and economic value: $155-166$. San Francisco, CA: Jossey-Bass.

Sen, A. K. 1999. Development as freedom. New York: Knopf.

Silverman, G. 2006. How may I help you? Financial Times, February 4/5: W1-2.

Simha, A., \& Carey, M. R. 2012. The encyclical letter (Caritas in veritate)—A shoutout to social entrepreneurship? The Journal of Entrepreneurship, 21(1): $1-23$.

Simonian, H. 2006. Nestle charts low-income territory. Financial Times, July 14: 15.

Smith, W. K., Besharov, M. L., Wessels, A. K., \& Chertok, M. 2012. A paradoxical leadership model for social entrepreneurs: Challenges, leadership skills, and pedagogical tools for managing social and commercial demands. Academy of Management Learning \& Education, 11(3): 463-478.

Social Investment Forum. 2006. 2005 report on socially responsible investing trends in the United States: 10-year review, http://www.ussif.org/files/ Publications/05_Trends_Report.pdf (accessed May 11, 2013).

Stoner, J. A. F. 2012. What we want this journal to be. Journal of Management for Global Sustainability, 1: 1-6.

U.S. Census Bureau. 2011. Poverty: Highlights, http://www.census.gov/hhes/www/ poverty/about/overview/index.html (accessed May 11, 2013).

United Nations. 1995. Copenhagen declaration on social development, http:// www.un-documents.net/cope-dec.htm (accessed May 11, 2013).

United Nations. 2002. Johannesburg declaration on sustainable development, http://www.un-documents.net/jburgdec.htm (accessed May 11, 2013).

United Nations Development Programme. 2011. Multidimensional poverty index (MPI), http://hdr.undp.org/en/statistics/mpi/ (accessed February 28, 2012).

Varman, R., Skalen, P., \& Belk, R. W. 2012. Conflicts at the bottom of the pyramid: Profitability, poverty alleviation, and neoliberal governmentality. Journal of Public Policy \& Marketing, 31(1): 19-35.

Vogel, D. J. 2005. Is there a market for virtue? The business case for corporate social responsibility. California Management Review, 47(Summer): 19-45.

World Economic Forum \& Boston Consulting Group. 2009. The next billions: Unleashing business potential in untapped markets, http://www3. weforum.org/docs/WEF_FB_UntappedMarkets_Report_2009.pdf (accessed May $11,2013)$.

Young, Y. 2006. "Fringe economy" preys on the poor. USA Today: A13.

Zahra, S. A., Gedajlovic, E., Neubaum, D. O., \& Shulman, J. M. 2009. A typology of social entrepreneurs: Motives, search processes and ethical challenges. Journal of Business Venturing, 24: 519-532. 


\section{APPENDIX A: SYNOPSIS OF THEORIES (LACZNIAK \& SANTOS, 2011)}

\section{Moral Philosophy and Religious Doctrine: Catholic Social Teaching}

Catholic social teaching (CST) comprises the tradition of Papal, Church Council, and Episcopal documents that deal with the Catholic Church's response and commitment to the social demands of the gospel in the context of the world. At the heart of CST are four principles that are referred to as the permanent principles of the Church's social doctrine (Pontifical Council for Justice and Peace, 2004). These are: dignity of the human person, the common good, subsidiarity, and solidarity.

1. Human dignity: The Church affirms that human life is sacred and human beings, by virtue of being created in God's image, have a certain "inviolable dignity." Therefore, all human persons, regardless of race, color, and creed, possess an inherent dignity of being in the likeness of God, and therefore, righteously, should be accorded full respect.

2. The common good: In its broad sense, the common good is understood as the social conditions that enable individuals or groups to attain their fulfillment more easily. Furthermore, each person should have access to the level of wellbeing necessary for his [or her] full development.

3. Subsidiarity: Basically, this principle holds that a greater or higher association should not do what a lesser and subordinate organization can do. The word subsidiarity comes from the Latin subsidium which means help. Thus, the principle of subsidiarity refers to helping or supporting others while respecting their initiatives and capabilities.

4. Solidarity: This principle affirms the intrinsic social nature of the human person and the awareness of the interdependence between individuals and peoples. Solidarity is a firm and persevering determination to commit oneself to the common good.

\section{Moral Philosophy and Religious Doctrine: Habermas' Discourse Theory}

The German philosopher Jürgen Habermas (1990) proposed that instead of postulating a priori moral norms, such as Kant's categorical imperative, one should arrive at these norms through a process of practical 
discourse. Habermas' discourse theory features moral agents who strive to put themselves in each others' place. Fairness, in discourse theory, is achieved by putting oneself in the place of every other party. Discourse theory, thus, places empathy and dialogue at the heart of the process for arriving at a reasoned agreement of what constitutes a valid moral norm (McCarthy, 2001; Nill \& Schultz, 1997).

\section{Moral Philosophy and Religious Doctrine: Kant's Categorical Imperative}

The philosopher Immanuel Kant is well-known for his duty based theory of ethics. For Kant, acting out of duty is not contingent upon potential outcomes but rather is based on adhering to fundamental laws that can be rationally designated as universal maxims. Kant (1785) called such a fundamental law the "categorical imperative," or the supreme principle of morality, and proposed the following three formulations:

1. Act only on maxims that you will to be universal laws of nature.

2. Always treat the humanity in a person as an end and never as a means merely.

3. Act as if you were a member of an ideal kingdom of ends in which you were both subject and sovereign at the same time.

\section{Moral Philosophy and Religious Doctrine: Rawls' Difference Principle}

The influential Harvard philosopher John Rawls (1971) uses a thought experiment called the "original position" to arrive at a conception of justice that should be acceptable and fair to all. In this position, individuals do not know in advance their future status in society (i.e., class position or social status, wealth, intelligence, strength, and so on). Rawls calls this condition a "veil of ignorance." Rawls (1999: 266) proposes that in this "original position," free and rational persons, wanting to further their own interests and at the same time wanting to minimize their social risk (as they do not know in advance what their "revealed" status will be), would arrive at two moral principles. These are:

1. Each person is to have an equal right to the most extensive total system of equal basic liberties compatible with a similar system of liberty for all; and 
2. Social and economic inequalities are to be arranged so that they are both (a) to the greatest benefit of the least advantaged, and (b) attached to offices and positions open to all under conditions of fair equality of opportunity.

The first part of the second principle is also known as the difference principle.

\section{Moral Philosophy and Religious Doctrine: Ross' Theory of Duties}

The Scottish-born moral philosopher Sir William D. Ross held that there are certain principles that we know intuitively because they are self-evident. Ross (1930) calls these principles prima facie (meaning at first sight) duties and lists six such duties. They are duties of (1) fidelity, (2) gratitude, (3) justice, (4) beneficence, (5) self-improvement, and (6) nonmaleficence.

\section{Moral Philosophy and Religious Doctrine: Sen's Capability Approach}

The Nobel Laureate Amartya Sen (1999) advocates broadening the framework of development economics. For Sen, economic growth should be considered not merely in monetary terms such as gross domestic product (GDP), aggregate income, or supply of goods and services, but in perspectives that involve expanding the capabilities, entitlements, and freedoms of people. According to Sen (1999: 75), a person's capabilities specifically refer to "the alternative combinations of functionings that are feasible for her [or him] to achieve." A capability then is "a kind of freedom: the substantive freedom to achieve alternative functioning combinations." Sen (1999: 17) considers the expansion of freedom the primary end as well as the principal means of development. The view of freedom here is one that "involves both the processes that allow freedom of actions and decisions and the actual opportunities that people have, given their personal and social circumstances." Sen (1999: 10) lists five distinct types of instrumental freedoms that are interconnected and complementary. These are: (1) political freedoms; (2) economic facilities; (3) social opportunities; (4) transparency guarantees; and (5) protective security. Each of these freedoms advances the general capability of a person.

\section{Moral Philosophy and Religious Doctrine: Virtue Ethics}

Virtue ethics is one of the oldest moral frameworks and focuses on the virtues and the perfection of personal character. A prominent and contemporary proponent of the virtue ethics tradition is the philosopher Alasdair MacIntyre. Virtues, according to MacIntyre (1984), are acquired 
human qualities that help develop personal character. While there is disagreement on the list of virtues, in the context of linking virtue ethics to international marketing, Murphy (1999: 113) proposes five core virtues that an ethical business organization should possess: (1) integrity, (2) fairness, (3) trust, (4) respect, and (5) empathy. Taken together, these virtues provide a helpful benchmark for what constitutes a virtuous firm.

\section{Managerial Frameworks: Socially Responsible Investing}

In the wake of corporate scandals in recent years, companies are beginning to realize that a substantial number of investors are not interested solely in the financial performance of a company-they are also concerned about social and environmental issues. According to the Social Investment Forum (2006), socially responsible investment (SRI) assets in the United States rose more than 258\% from \$639 billion in 1995 to $\$ 2.29$ trillion in 2005. At the same time, the question of whether or not socially responsible firms outperform those that are not has not yet been definitively answered, if it ever can be. Vogel (2005: 42), for instance, reviewed academic studies of the relationship between profitability and social responsibility and concluded that there is "little support for the claim that more responsible firms are more profitable." However, the fact that SRI assets over a ten year period from 1995 to 2005 increased four percent faster than the entire universe of managed assets in the United States is indicative of a marked shift in investor preferences (Social Investment Forum, 2006). This return level is also indicative of the notion that SRI is not the naive financial strategy that some of its early critics made it out to be (Glassman, 1999).

\section{Managerial Frameworks: Stakeholder Theory}

In contrast to shareholder theory which holds that a firm's exclusive responsibility is to its shareholders (Friedman, 1962, 1970), stakeholder theory maintains that a firm has a responsibility to other constituencies that have a stake in it (Freeman, 1984). Freeman, Harrison, and Wicks (2007) define a stakeholder as "any group or individual who can affect or is affected by the achievement of a corporation's purpose" (p. 6) and point out that "value creation is a joint process that makes each primary stakeholder better off" (p. 52). In other words, there does not have to be any trade-off involved, meaning that the interests of some stakeholders do not have to be sacrificed in favor of the interests of other stakeholders. For the interests of stakeholders to be better served, Freeman, Harrison, and Wicks (2007: 112) recommend that managers should "put 
themselves in the stakeholder's place and try to empathize with that stakeholder's position."

\section{Managerial Frameworks: Global Sustainability Perspective}

With the growing awareness of climate change and global warming, there is a temptation to limit thinking about the scope of sustainability to just the threats to the environment. However, as the Copenhagen Declaration at the 1995 World Summit on Social Development pointed out, "economic development, social development, and environmental protection are interdependent and mutually reinforcing components of sustainable development" (United Nations, 1995). This understanding was further developed at the 2002 World Summit on Sustainable Development at Johannesburg which stated that "poverty eradication, changing consumption and production patterns, and protecting and managing the natural resource base for economic and social development are overarching objectives of and essential requirements for sustainable development" (United Nations, 2002). This journal, of course, joins many sustainability experts and leaders in taking a broad, encompassing, and integrative view of the inherent nature of global sustainability.

\section{Managerial Frameworks: Triple Bottom Line}

A prominent advocate for the Triple Bottom Line (3BL) concept is John Elkington (1998). The 3BL approach basically calls for an enlarged mindset that moves from an exclusive focus on financial measures and toward considering the social and environmental aspects of the business as well. While current profits are an indicator that a business may be functioning well in the economic domain, a preoccupation with short-term financial returns can ironically act against the long-term interests and survival of the corporation. A mania by management concerning short run financial hurdles can, in numerous cases, reduce the ability of the firm to position itself advantageously for future business opportunities, create resentment among stakeholders, and engender costly regulation.

\section{APPENDIX B: THEORETICAL SUPPORT FOR IJM PROPOSITIONS (LACZNIAK \& SANTOS, 2011)}

Proposition: Authentic engagement with consumers, particularly impoverished ones, with non-exploitative intent 
Theory:

- Catholic Social Teaching [common good, human dignity, solidarity]

- $\quad$ Kant's Categorical Imperative $\left[1^{\text {st }}\right.$ and $2^{\text {nd }}$ formulation]

- $\quad$ Ross' Theory of Duties

- $\quad$ Service-Dominant Logic of Marketing

- Virtue Ethics

Proposition: Co-creation of value with customers, especially those who are impoverished or disadvantaged

Theory:

- Catholic Social Teaching [human dignity, subsidiarity]

- Habermas' Discourse Theory

- Kant's Categorical Imperative [3rd formulation]

- $\quad$ Service-Dominant Logic of Marketing

Proposition: Investment in future consumption without endangering the environment

Theory:

- Catholic Social Teaching [common good, human dignity]

- Classical Utilitarianism

- Sen's Capability Approach

- $\quad$ Service-Dominant Logic of Marketing

- Sustainability Perspective

Proposition: Interest representation of all stakeholders, particularly impoverished customers

Theory:

- Catholic Social Teaching [common good, subsidiarity]

- Classical Utilitarianism

- Habermas' Discourse Theory

- Kant's Categorical Imperative [2nd formulation]

- Rawls' Difference Principle

- $\quad$ Service-Dominant Logic of Marketing

- Stakeholder Theory

- Global Sustainability Perspective 
Proposition: Focus on long-term profit management rather than short-term profit maximization

Theory:

- Catholic Social Teaching [common good]

- Classical Utilitarianism

- $\quad$ Service-Dominant Logic of Marketing

- $\quad$ Socially Responsible Investing

- Triple Bottom Line

- Global Sustainability Perspective

\section{APPENDIX C: AN INTEGRATIVE JUSTICE MODEL FOR IMPOVERISHED MARKETS (SANTOS \& LACZNIAK, 2009A)}

\section{VALUE INPUTS}

- Authentic engagement with consumers, particularly impoverished ones, with non-exploitative intent

- Co-creation of value with customers, especially those who are impoverished or disadvantaged

- Investment in future consumption without endangering the environment

- Interest representation of all stakeholders, particularly impoverished customers

- Focus on long-term profit management rather than short-term profit maximization

BUSINESS FIRM

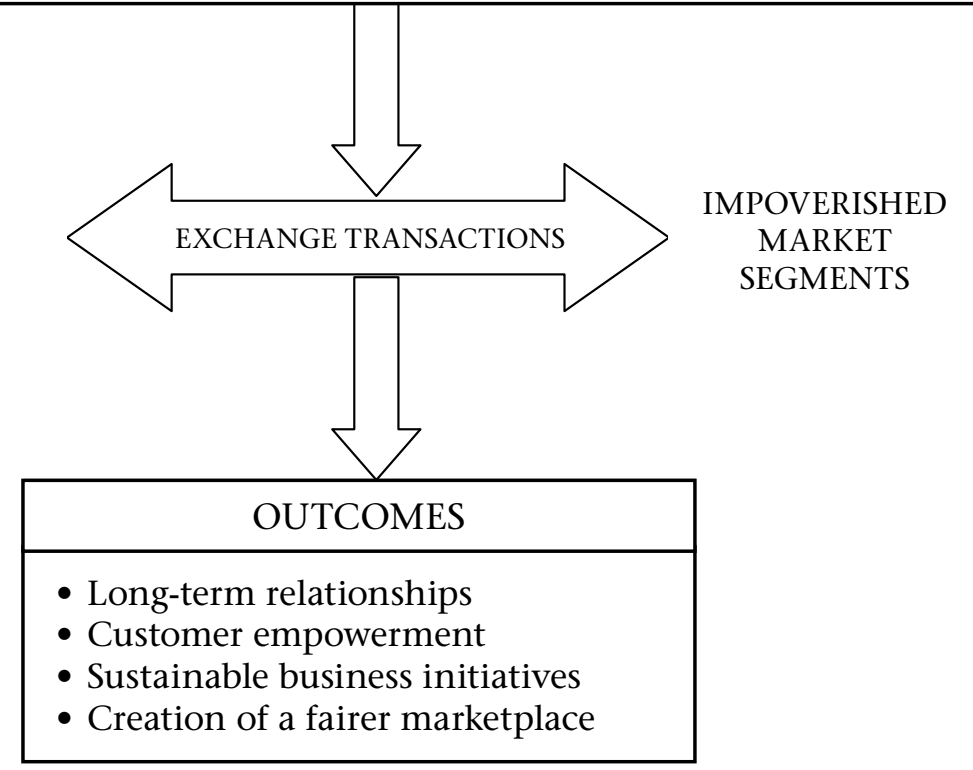




\section{APPENDIX D: IJM DECISION PRINCIPLES FOR MNC MANAGERS (SANTOS \& LACZNIAK, 2012)}

IJM Element 1: Authentic engagement with non-exploitative intent

a. Develop trust with customers at all levels.

b. Build competitive advantage through a process of collaboration rather than focusing on eliminating competition.

c. Subscribe to a long-term perspective which holds that improving the quality of society and the environment is to the benefit of all.

d. Never take advantage of the relative weaknesses of customers. Instead, the company should make maximum efforts, using its own relative strengths to relieve these shortcomings, so that the consumer experience is enhanced. In effect, companies ought to build a trustworthy reputation for fair dealing, dependability, and continuous care.

e. Encourage employee volunteering, particularly in impoverished neighborhoods.

f. Foster social sustainability while ensuring profitability in the long run.

g. Support the formalization of consumer rights that guarantee safety, redress, sufficient information, and other basic requirements of exchange fairness.

\section{IJM Element 2: Co-creation of value}

a. Instead of autonomously positing what constitutes value for impoverished consumers, involve such consumers in the value-creation process itself.

b. Use resources to ensure that the company's fairly priced offering proposes what is of best economic value for its targeted impoverished customers.

c. Engage in a co-creation process that fosters sustained partnerships and develops mutual trust with impoverished customers that extends beyond the consumption of the product or service. 
d. Leverage local innovativeness and actively seek ways in which impoverished customers can participate in the value co-creation process.

e. Constantly seek input from the company's impoverished customers either directly or through observation, and incorporate this feedback into decision-making processes.

f. Consider ways in which impoverished customers can be given an ownership stake in the company.

g. Partner with local NGOs so as to leverage the expertise, goodwill, and network of the NGOs in a mutually advantageous manner.

h. Collaborate with the local community so as to tap into the social networks they constitute.

\section{IJM Element 3: Investment in future consumption}

a. Invest in research and development aimed at developing innovations for impoverished markets that are both socially beneficial and environmentally friendly.

b. Strive to increase the capabilities of impoverished segments to ensure that these impoverished segments can better participate in the market economy.

c. Pay employees a living wage to ensure that they can contribute to the overall economy of which the firm is also a part.

d. In the conception, production, and delivery of goods or services, strive to ensure that the ecological footprint is minimized.

e. In keeping with an emerging global sustainability perspective, a business firm in impoverished markets ought to afford access to products and services (e.g., leasing or sharing) rather than focus on ownership of these.

\section{IJM Element 4: Interest representation of all stakeholders}

a. Consider what matters to the company's stakeholders and what is to their advantage. Furthermore, demonstrate through business policies and ethical audits that such accommodations have indeed taken place. 
b. Treat impoverished customers as primary stakeholders since they have a continuing and essential interest in the firm, and are also vital to the growth and survival of the business initiative once a commitment to target this segment is made.

c. Encourage employees to have first-hand experience of the real world of low-income consumers.

d. Ensure that promulgated decisions, actions, and procedures do not further disadvantage impoverished customers.

e. Engage in dialogue with impoverished customers about the company's products and services to ensure a greater likelihood of the customers' interests being taken into account.

f. Make efforts to understand the difficulties and constraints faced by impoverished customers and try to alleviate these so as to enhance the overall consumer experience. This strategy might involve investing in education, health care, sanitation, and access to credit that expand the capabilities of impoverished consumers and enable a richer firmconsumer relationship.

g. Include consumer education and counseling as part of the marketing strategy to ensure better representation of the long-term interests of impoverished customers and to enable customers to make better informed choices.

h. Develop and promote products and services that are especially relevant to the impoverished market segment.

i. Enable impoverished customers to have better access to the market in order for them to better participate in the market economy.

j. Make the company's products and services affordable, accessible, and available.

k. Ensure that information about the company's products and services is easily understood by its impoverished customers.

\section{IJM Element 5: Long-term profit management}

a. Instead of seeking to maximize financial returns in the short run, aim at creating sustainable value in the long run. 
b. Consistent with the role of a social as well as an economic institution, consider social goals as ends in themselves rather than as means to a financial end.

c. Increase business success with a long-term perspective based on social, environmental, and financial returns.

d. View impoverished markets as sources of opportunity, innovation, and competitive advantage.

e. Support local communities in their holistic development in terms of supporting education, health, sports, the arts, etc. at a scale and focus befitting the local community and culture. 